\title{
CARDIOPULMONARY AND ACID-BASE EFFECTS OF TRAMADOL IN CATS ANESTHETIZED WITH SEVOFLURANE
}

\author{
EFEITO CARDIOPULMONAR E ÁCIDO BÁSICO DO TRAMADOL EM GATAS \\ ANESTESIADAS PELO SEVOFLURANO
}

\begin{abstract}
Moacir Santos de LACERDA ${ }^{1}$; Renato Linhares SAMPAIO ${ }^{2}$; Rodrigo Supranzetti de REZENDE ${ }^{3}$; Thiago Cunha NUNES ${ }^{4}$

1. Professor, DMV, MS, PhD., Department of Veterinary Surgery and Anestesiology, Faculty of Veterinary Medicine, University of Uberaba, Uberaba, MG, Brazil. moacir.lacerda@uniube.br; 2. Professor, DMV, MS, PhD., Department of Veterinary Surgery and Anestesiology, Faculty of Veterinary Medicine, University of Uberaba, Uberaba, MG, Brazil; 3. Professor, DVM, Msc., Department of Clinical Veterinary, Faculty of Veterinary Medicine, University of Uberaba, Uberaba, MG, Brazil; 4. Veterinarian, DVM, MSc., Veterinary Hospital of Uberaba, Faculty of Veterinary Medicine, University of Uberaba, Uberaba, MG, Brazil.
\end{abstract}

\begin{abstract}
The experiment assessed the cardiorespiratory and hemogasometric profiles in female cats under sevoflurane resulting from the administration of tramadol. Twenty clinically healthy adult female cats separated equally into two groups: control group (CG) and tramadol group (TG) were sedated with intramuscular acepromazine (0.05 $\mathrm{mg} / \mathrm{kg}$ ), followed by anesthetic induction intravenous propofol $(5 \mathrm{mg} / \mathrm{kg})$. After endotracheal intubation, animals were maintained on sevoflurane in oxygen administered using a non-rebreathing (Baraka) circuit. The oxygen flow-rate was maintained at $2 \mathrm{~L}$ per minute. Fifteen minutes after induction, either $0.05 \mathrm{ml} / \mathrm{kg} 0.9 \%$ saline solution or $2 \mathrm{mg} / \mathrm{kg}$ tramadol were administered, both intramuscularly, to the animals in $\mathrm{CG}$ and $\mathrm{TG}$, respectively. The period of time immediately previous to these administrations was considered as moment zero (T0). The variables were again measured 15 minutes later (T15) and subsequently in 15 minute intervals for a total of sixty minutes (T30, T45 and T60). The results were statistically evaluated through variance analysis of repeated measures (ANOVA) followed by a Tukey test or Student t-test with the nullity hypothesis rejection level set to $\mathrm{p}<0.05$. The use of tramadol reduced cardiac frequency $(\mathrm{CF})$, systolic arterial pressure (SAP), diastolic arterial pressure (DAP) and mean arterial pressure (MAP). There was a reduction of the respiratory frequency (RF) and an elevation of the $\mathrm{PaCO}_{2}$. The body temperature $\left({ }^{\circ} \mathrm{C}\right)$ lowered in both groups throughout the experiment. The results allow us to conclude that tramadol in cats anesthetized with sevoflurane does not undergo significant cardiorespiratory and blood-gas changes, although there are significant differences in some parameters between groups, all results remained within feline standard physiological values.
\end{abstract}

KEYWORDS: Felis catus. Opioids. Anesthesia.

\section{INTRODUCTION}

Sevoflurane is a non-flammable isopropylic fluorited volatile anesthetic that has been routinely used since 1990 (RESENDE et al., 2000; MASSONE, 2008). This inhalational anesthetic affects the cardiovascular system through reduction of mean arterial pressure, increase of myocardial contractility, without sensitizing the myocardium to the action of epinephrine (NAVARRO et al., 1994) and slight increase of heart rate (BERNARD et al., 1990; BERNARD et al., 1992). The increase in heart rate is not adequate to maintain proper cardiac output, because the peripheral vascular resistance is decreased. (HIKASA et al., 1997). When compared to the effects of other volatile anesthetics used in humans, sevoflurane seems to be one of those that offer better cardiovascular stability (EBERT, HARKIN, MUZI, 1995)

Sevoflurane does not promote significant respiratory rate changes when compared to isoflurane (HIKASA et al., 1996). Moreover, in cats, the degree of hypercapnia and acidosis produced by sevoflurane does not differ from that caused by isoflurane, and is less than that when compared with induction by halothane or enflurane (HIKASA et al., 1997). In cats, the degrees of hypercapnia and acidosis are lower when sevoflurane is used (PYPENDOP, ILKIW, 2004)

Sevoflurane anesthesia in female cats spontaneously ventilated can induce respiratory acidosis and increase in carbon dioxide at the end of expiration (SOUZA et al., 2005). Given that sevoflurane has only recently been introduced to feline anesthesia, there are not many studies carried out in cats (MOUTINHO, 2010).

Tramadol is an analgesic with a dual mechanism of action. It both binds to the $\mu \mathrm{L}$ opioid receptor as agonist (GUEDES et al., 2005; KUKANICH, PAPICH, 2005) and inhibits the monoaminergic pathway which is responsible for noradrenaline (NA) and serotonin (5HT) reuptake (KUBOTA et al., 2008; MCMILLAN et al., 2008). For this reason, tramadol is considered an "atypical opioid" and is only partially inhibited by naloxone, an opioid antagonist (FANTONI, 2010). Preemptive 
administration of tramadol has been performed to significantly reduce the amount of inhalant anesthetic required for procedures in humans (WORDLICZEK et al., 2002) and dogs (OZKURT, 2002; SEDDIGHI et al., 2009)

Several clinical studies have reported the absence of significant respiratory depression using an analgesic dose of tramadol (RADBRUCH, GROND, LEHMANN, 1996). Other studies, however, have indicate that under some circumstances, tramadol may cause respiratory depression (TEPPEMA et al., 2003)

The aim of this study was to assess the cardiopulmonary and acid base effects of tramadol in cats anesthetized by sevoflurane.

\section{MATERIAL AND METHODS}

This study was approved by the University of Uberaba's Animal Experimentation Ethics Committee (CEEA). Twenty clinically healthy adult female cats, weighing between 2 and 3 kilograms $\left(2.5^{ \pm} 0.5 \mathrm{~kg}\right)$ were used. The cats were housed individually in stainless steel cages and fed commercial dry food and water ad libitum. Food was withdrawn 8 to 12 hours and water 2 hours before anesthesia. After fully recovering from anesthesia, animals were returned to their cages and fed as described previously.

\section{Anesthetic procedures}

The cats were separated into two groups of ten animals each: Control Group (CG) or Treated Group (TG). Animals received as premedication acepromazine maleate (Vetnil Ltda) $(0.05 \mathrm{mg} / \mathrm{kg})$ intramuscularly. All cats were induced with intravenous propofol (Propovan, Cristália) at 5 $\mathrm{mg} / \mathrm{kg}$ and were intubated with endotracheal tubes (size range: 3.0-4.0). Anesthesia was maintained with sevoflurane (Sevocris, Cristália) diluted in $100 \%$ oxygen at a flow rate of $300 \mathrm{ml} / \mathrm{kg} / \mathrm{min}$, through a Baraka (Oxigel) system fed by a universal vaporizer. Fifteen minutes after anesthetic induction, animals were intramuscularly treated with $0.05 \mathrm{ml} / \mathrm{kg} \mathrm{0.9 \%}$ saline (Eurofarma) (CG) or $2 \mathrm{mg} / \mathrm{Kg}$ tramadol (Tramadon; Cristália) (TG).

\section{Cardiopulmonary measurements}

The following parameters were measured:

- Heart rate (HR), using the R-R interval, obtained from a computerized electrocardiograph (TEB - ECGPC VET);

- Hemoglobin Oxigen saturation was obtained, as a percentage (\%), from an
LACERDA, M. S. et al.

oximeter attached to the animal's tongue (Omni 600 - Omnimed).

- Systolic (SAP), diastolic (DAP) and mean (MAP) arterial pressures were measured from time zero (T0) to time sixty (T60) using an oscillometric pressure monitor (Omni 600 - Omnimed).

- Respiratory rate (RR) and end-tidal carbon dioxide partial pressure $\left(\mathrm{PETCO}_{2}\right)$, were obtained through the use of a multiparametric monitor (Omni 600 Omnimed) with the sensor placed between the tracheal tube and the anesthesia circuit;

- Arterial $\mathrm{pH}(\mathrm{pH})$, arterial partial pressure of carbon dioxide $\left(\mathrm{PaCO}_{2}\right)$, arterial partial pressure of oxygen $\left(\mathrm{PaO}_{2}\right)$, plasma bicarbonate $\left(\mathrm{HCO}_{3}\right)$, base deficit $(\mathrm{BD})$ and arterial oxygen saturation $\left(\mathrm{SaO}_{2}\right)$ were measured from arterial blood samples, drawn from the femoral artery, and immediately analyzed by a digital blood gas analyzer (Clinical Analyzer OMINI-CRoche), which is designed to calibrate automatically each time a new cartridge is inserted.

Before the anesthetic induction, the hair was clipped from the right femoral triangle and $1 \mathrm{ml}$ of lidocaine chlorhydrate (Xylestesin, Cristália) was infiltrated over the femoral artery. The femoral artery was then exposed through a skin incision to allow puncture of the artery in order to collect the first blood sample (T0). For the other measurements (T15-T60) the blood samples were collected through the same catheter used for the measurement of the arterial blood pressure.

The measurements began right before the tramadol and the saline were administered (T0) and the following blood drawn and data recording took place in 15 minute intervals for 60 minutes (T15, T30, T45 e T60) during volatile anesthesia.

\section{Statistical analyses}

Data were analyzed by one-way analysis of variance for repeated measurements to compare time-related variables within each anesthetic group followed by Tukey's test used to estabilish mean values within the same group. The significance level of all tests was set at $5 \%$.

\section{RESULTS}

Control Group's HR did not significantly change among recorded times, while within the tramadol group (TG) the heart rate decreased. The 
respiratory frequency average within the control group was significantly higher than the observed into the tramadol group, especially from T30 until the end of the experiment. No important variation in body temperature (BT) was recorded. Within the three different kinds of blood pressure evaluated, control group's (CG) averages were consistently lower than those recorded into the tramadol group (TG) from T15 until T60. When studying the groups separately, CG did not exhibit differences between times. On the other hand, TG (tramadol group) did show a decrease in the measured pressure values from $\mathrm{T} 15$ to $\mathrm{T} 60$. The analysis of the TG $\mathrm{SpO}_{2}$ showed significant difference at T30. Results obtained for $\mathrm{PETCO}_{2}$ did not show differences between the groups. When analyzed within the groups, GT showed higher $\mathrm{PETCO}_{2}$ averages from T30 to T60 (Table 1).

The blood gas analyses showed no significant reduction of the $\mathrm{pH}$ baseline values with the administration of tramadol and were stable throughout the experiment.

The $\mathrm{PaO}_{2}$ values remained constant within the groups during anesthesia. The $\mathrm{PaCO}_{2}$ increased in both groups with anesthesia (CG and TG) and remained constant until the end of the experimental period. Statistical difference was observed only at T60 which GT mean value of $\mathrm{PaCO}_{2}$ was lower than T0.

$\mathrm{SaO}_{2}$ remained at $100 \%$ for both groups throughout the anesthetic period. $\mathrm{BD}$ and $\mathrm{HCO}_{3}$ did not change significantly during anesthesia within groups and between groups (Table 2).

Table 1. Mean values ( \pm standard deviations) for heart (HR) and respiratory (RR) rates; partial pressure of end tidal carbon dioxide $\left(\mathrm{PETCO}_{2}\right)$, systolic (SAP), diastolic (DAP) and mean (MAP) arterial pressures of cats anesthetized with sevoflurane and treated with $0.9 \%$ sodium chloride (GC) or with tramadol (GT).

\begin{tabular}{|c|c|c|c|c|c|c|}
\hline Variables & & T0 & T15 & T30 & T45 & T60 \\
\hline HR (beats/min) & $\begin{array}{l}\text { GC } \\
\text { GT }\end{array}$ & $\begin{array}{l}121.7 \pm 10.24 \\
127.1 \pm 22.12\end{array}$ & $\begin{array}{c}122.4 \pm 10.69^{\#} \\
104.2 \pm 13.05^{\text {*\# }}\end{array}$ & $\begin{array}{c}118.7 \pm 13.33^{\#} \\
98.8 \pm 7.77^{* \#}\end{array}$ & $\begin{array}{l}118.8 \pm 11.75^{\#} \\
100.7 \pm 7.61^{\text {*\# }}\end{array}$ & $\begin{array}{c}117.9 \pm 10.02^{\#} \\
101.7 \pm 14.25^{\text {*\# }}\end{array}$ \\
\hline $\mathbf{R R}$ (mpm) & $\begin{array}{l}\text { GC } \\
\text { GT }\end{array}$ & $\begin{array}{l}14.1 \pm 4.17 \\
14.1 \pm 4.88\end{array}$ & $\begin{array}{l}16.1 \pm 4.14^{\#} \\
10.5 \pm 4.11^{\text {*\# }}\end{array}$ & $\begin{array}{l}15.8 \pm 3.64^{\#} \\
9.2 \pm 3.25^{* \#}\end{array}$ & $\begin{array}{l}16.3 \pm 3.88^{\#} \\
9.5 \pm 3.20^{* \#}\end{array}$ & $\begin{array}{c}14.2 \pm 4.31^{\#} \\
10.6 \pm 3.47^{* \#}\end{array}$ \\
\hline BT $\left({ }^{\circ} \mathrm{C}\right)$ & $\begin{array}{l}\text { GC } \\
\text { GT }\end{array}$ & $\begin{array}{l}37.4 \pm 0.51 \\
37.5 \pm 0.70\end{array}$ & $\begin{array}{l}37.3 \pm 0.48 \\
37.1 \pm 0.73\end{array}$ & $\begin{array}{l}37.1 \pm 0.56 \\
36.8 \pm 0.63\end{array}$ & $\begin{array}{l}36.9 \pm 0.56 \\
36.6 \pm 0.51\end{array}$ & $\begin{array}{l}36.7 \pm 0.67 \\
36.3 \pm 0.48\end{array}$ \\
\hline PAS (mmHg) & $\begin{array}{l}\text { GC } \\
\text { GT }\end{array}$ & $\begin{array}{l}113.5 \pm 15.79 \\
114.4 \pm 11.03\end{array}$ & $\begin{array}{l}113.7 \pm 12.8^{\#} \\
90.6 \pm 12.1^{* \#}\end{array}$ & $\begin{array}{c}113.1 \pm 12.37^{\#} \\
92.7 \pm 8.7^{* \#}\end{array}$ & $\begin{array}{l}113.8 \pm 13.2^{\#} \\
92.7 \pm 7.93^{* \#}\end{array}$ & $\begin{array}{l}114.2 \pm 11.3^{\#} \\
93.5 \pm 6.90^{* \#}\end{array}$ \\
\hline PAD $(\mathrm{mmHg})$ & $\begin{array}{l}\text { GC } \\
\text { GT }\end{array}$ & $\begin{array}{l}63.3 \pm 13.45 \\
66.6 \pm 10.78\end{array}$ & $\begin{array}{l}65.4 \pm 15.29^{\#} \\
46.9 \pm 8.39^{* \#}\end{array}$ & $\begin{array}{l}64.7 \pm 15.37^{\#} \\
46.8 \pm 8.80^{* \#}\end{array}$ & $\begin{array}{l}62.6 \pm 14.62^{\#} \\
46.5 \pm 9.53^{* \#}\end{array}$ & $\begin{array}{c}62.2 \pm 13.94^{\#} \\
47.1 \pm 11.87^{* \#}\end{array}$ \\
\hline PAM (mmHg) & $\begin{array}{l}\text { GC } \\
\text { GT }\end{array}$ & $\begin{array}{c}84.1 \pm 11.77 \\
86.0 \pm 9.93\end{array}$ & $\begin{array}{c}85.2 \pm 12.06^{\#} \\
63.5 \pm 10.63^{* \#}\end{array}$ & $\begin{array}{l}84.1 \pm 11.35^{\#} \\
64.9 \pm 7.72^{* \#}\end{array}$ & $\begin{array}{l}82.7 \pm 12.32^{\#} \\
65.1 \pm 8.22^{* \#}\end{array}$ & $\begin{array}{l}82.4 \pm 11.84^{\#} \\
65.6 \pm 10.15^{* \#}\end{array}$ \\
\hline $\mathrm{SPO}_{2}$ & $\begin{array}{l}\text { GC } \\
\text { GT }\end{array}$ & $\begin{array}{l}96.0 \pm 1.56 \\
97.6 \pm 1.07\end{array}$ & $\begin{array}{l}96.4 \pm 0.96 \\
96.7 \pm 1.70\end{array}$ & $\begin{array}{c}94.4 \pm 2.06 \\
92.8^{*} \pm 5.32\end{array}$ & $\begin{array}{l}93.7 \pm 3.52 \\
96.2 \pm 2.74\end{array}$ & $\begin{array}{l}96.1 \pm 2.13 \\
95.0 \pm 2.94\end{array}$ \\
\hline $\begin{array}{c}\mathrm{PETCO}_{2} \\
(\mathrm{mmHg})\end{array}$ & $\begin{array}{l}\text { GC } \\
\text { GT }\end{array}$ & $\begin{array}{l}26.7 \pm 6.36 \\
24.2 \pm 4.07\end{array}$ & $\begin{array}{l}25.9 \pm 4.58 \\
30.5 \pm 3.86\end{array}$ & $\begin{array}{c}30.7 \pm 4.69 \\
32.1 \pm 3.07^{*}\end{array}$ & $\begin{array}{l}32.1 \pm 4.20 \\
32.9 \pm 4.38^{*}\end{array}$ & $\begin{array}{l}30.5 \pm 3.40 \\
31,8 \pm 3.32^{*}\end{array}$ \\
\hline
\end{tabular}

* Significant variation compared to T0 $(\mathrm{p}<0.05)$; \# Significant variation between groups at the same time $(\mathrm{p}<0.05)$ 
Table 2. Mean values ( \pm standard deviations) for arterial blood $\mathrm{pH}(\mathrm{pH})$, arterial partial pressure of oxygen $\left(\mathrm{PaO}_{2}\right)$ and carbon dioxide $\left(\mathrm{PaCO}_{2}\right)$; base deficit $(\mathrm{BD})$, arterial oxygen saturation $\left(\mathrm{SaO}_{2}\right)$ and bicarbonate ion concentration $\left(\mathrm{HCO}_{3}\right)$ of cats anesthetized with sevoflurane and treated with $0.9 \%$ sodium chloride (GC) or with tramadol (GT).

\begin{tabular}{ccccccc}
\hline Variables & & T0 & T15 & T30 & T45 & T60 \\
\hline $\mathbf{p H}$ & GC & $7.29 \pm 0.05$ & $7.29 \pm 0.04$ & $7.29 \pm 0.04$ & $7.25 \pm 0.04$ & $7.30 \pm 0.02$ \\
& GT & $7.26 \pm 0.06$ & $7.26 \pm 0.03$ & $7.26 \pm 0.06$ & $7.13 \pm 0.05$ & $7.25 \pm 0.05$ \\
$\mathbf{P a C O}_{\mathbf{2}}$ & GC & $29.7 \pm 4.66$ & $34.2 \pm 4.04$ & $29.0 \pm 3.55$ & $33.10 \pm 5.23$ & $33.70 \pm 2.54$ \\
$(\mathbf{m m H g})$ & GT & $30.10 \pm 4.06$ & $33.0 \pm 3.49$ & $31.1 \pm 3.75$ & $35.9 \pm 2.76$ & $36.2 \pm 5.11^{*}$ \\
& & & & & & \\
$\mathbf{P a O}_{2}$ & GC & $445.4 \pm 26.87$ & $472.2 \pm 26.07$ & $476.3 \pm 27.39$ & $474.5 \pm 35.58$ & $482.2 \pm 34.47$ \\
& GT & $466.6 \pm 34.15$ & $451.7 \pm 35.74$ & $475.1 \pm 31.33$ & $470.0 \pm 31.78$ & $476.6 \pm 31.44$ \\
$\mathbf{H C O}_{\mathbf{3}}{ }^{-}$ & GC & $19.3 \pm 2.45$ & $18.4 \pm 1.95$ & $19.1 \pm 2.23$ & $19.6 \pm 1.97$ & $18.3 \pm 1.15$ \\
$(\mathbf{m E q} / \mathbf{L})$ & GT & $18.5 \pm 1.58$ & $19.1 \pm 1.52$ & $18.0 \pm 1.94$ & $17.1 \pm 2.07$ & $18.4 \pm 2.11$ \\
& & & & & \\
$\mathbf{D B}$ & GC & $-2.3 \pm-2.54$ & $-2.0 \pm 3.05$ & $-2.1 \pm 2.55$ & $-1.9 \pm 2.68$ & $-2.1 \pm 2.55$ \\
$(\mathbf{m E q} / \mathbf{L})$ & GT & $-2.5 \pm 2.32$ & $-1.9 \pm 2.13$ & $-1.9 \pm 2.28$ & $-0.8 \pm 2.29$ & $-1.2 \pm 2.40$ \\
& & & & & & \\
$\mathbf{S a O}_{\mathbf{2}}(\%)$ & GC & $100 \pm 0.0$ & $100 \pm 0.0$ & $100 \pm 0.0$ & $100 \pm 0.0$ & $100 \pm 0.0$ \\
\hline
\end{tabular}

* Significant variation compared to T0 $(\mathrm{p}<0.05)$; \# Significant variation between groups at the same time $(\mathrm{p}<0.05)$

\section{DISCUSSION}

Since the objective of this study was to evaluate blood gas and cardiorespiratory changes elicited by tramadol during sevoflurane anesthesia, it was decided the laboratorial and clinical parameters assessed should be those most commonly practiced routinely.

Sevoflurane did not alter HR, on the other hand, within the treated group, tramadol induced a negative chronotropic effect, reducing the HR 15 minutes after its administration, remaining unchanged until the end of experiment (MILDH, 2007). Such event is related to the increase in vagal activity elicited by tramadol (BOVILL, SEBEL, STANLEY, 1984) although this effect is more evident when tramadol is administered intravenously compared to intramuscularly used in this study. Tramadol reduced the HR significantly of $\mathrm{TG}$, from T15 when compared to the CG and also from TG when compared to T0, in other words, administration of tramadol will reduce the HR (T15T60).

The RR behaved differently between CG and TG and presented significant differences between them, demonstrating reduction in RR from moment 30 (after tramadol injection) and remaining lower throughout the rest of the experiment. The association may produce a more severe respiratory depression, once opioids are respiratory system depressants (BOVILL, SEBEL, STANLEY, 1984).
Most anesthetics promote a progressive and gradual reduction in body temperature. This takes place due to several factors such as basal metabolism decrease, arterial pressure lowering, peripheral vasodilation and body surface area (NUNES, 1995). Since there was no significative difference between groups throughout the experiment, it becomes evident that the temperature reduction did not influence negatively the other observed variables.

The arterial blood pressure decreased within the group control, which could be attributed to a decrease in the systemic vascular resistance (SVR) caused by the volatile anesthetics (NAVARRO et al., 1994; CLARKE et al., 1996; SANTOS et al., 2013). However, the use of tramadol in TG caused a decrease in the systolic, diastolic and mean arterial blood pressures due to the depressant action of tramadol (MONTEIRO et al., 2009).

There has been a significant difference in blood pressure within the TG at moment 15 , which coincided with the reduction of the HR, thus reducing tissue perfusion (WHITE et al., 1990).

The increase in $\mathrm{PETCO}_{2}$, along with the inevitable $\mathrm{PaCO}_{2} \quad$ increase, stimulates chemosensitive areas within the medulla oblongata, thus stimulating breathing, allowing more $\mathrm{CO}_{2}$ to be eliminated through the lungs. However, if there should be a respiratory depression this process may be hindered (ÉVORA et al., 1999). The fact that tramadol produced significant increase in $\mathrm{PaCO}_{2}$ 
only 60 minutes after its administration is justifiable once events that influence the respiratory dynamics do not produce immediate responses, thus, sometime is necessary for the decrease in RR to influence blood $\mathrm{PaCO}_{2}$ for it can be detectable by blood gas (CLARKE et al., 1996).

$\mathrm{PaO}_{2}, \mathrm{HCO}_{3}, \mathrm{DB}$ e $\mathrm{pH}$ values did not vary significantly neither within different moments nor between both groups.

\section{CONCLUSION}

The results allow us to conclude that tramadol in cats anesthetized with sevoflurane does not cause significant cardiorespiratory and blood gas changes. Although there are significant differences in some parameters between groups, all results remained within feline physiological averages.

\section{ACKNOWLEDGEMENTS}

This study received no specific grant from any funding agency in the public, commercial, or not-for-profit sectors.

RESUMO: Avaliaram-se os efeitos cardiorespiratórios e hemogasométricos decorrentes da aplicação do tramadol em gatas anestesiadas pelo sevoflurano. Utilizaram-se vinte gatas adultas, clinicamente saudáveis separadas igualmente em dois grupos GC e GT, todos receberam $0,05 \mathrm{mg} / \mathrm{kg}$ de acepromazina pela via intramuscular como medicação pré anestésica e induzidos à anestesia com propofol, por via intravenosa, na dose de $5 \mathrm{mg} / \mathrm{kg}$. Após a intubação com sonda orotraqueal de Magill, manteve-se anestesia inalatória com sevoflurano, diluído em O2 a $100 \%$ (300 $\mathrm{mL} / \mathrm{kg} / \mathrm{min}$ ), por meio de sistema Baraka. Decorridos 15 minutos da indução anestésica foram administrados $0,05 \mathrm{~mL} / \mathrm{kg}$ de solução de cloreto de sódio a $0,9 \%$ ou $2 \mathrm{mg} / \mathrm{kg}$ de tramadol, ambos por via intramuscular, respectivamente, aos animais do GC e GT. Considerou-se o período imediatamente anterior a estas aplicações como o momento zero (M0) para o registro dos parâmetros. Novas mensurações foram realizadas a intervalos de 15 minutos, por um período de 60 minutos (T15, T30, T45 e T60). Os dados numéricos obtidos foram submetidos à análise de variância (ANOVA) seguida pelo teste Tukey ou teste t-Student, sendo considerado o nível de significância de $\mathrm{p}<0,05$. A administração do tramadol reduziu a frequência cardíaca (FC), pressões arteriais sistólica (PAS), diastólica (PAD) e média (PAM). Ocorreu redução da frequência respiratória (FR) e elevação da $\mathrm{PaCO}_{2}$ e a temperatura corporal $\left(\mathrm{T}^{\circ} \mathrm{C}\right)$ apresentou redução em ambos os grupos durante todo o período experimental. Os resultados permitem concluir que a administração do tramadol em gatas anestesiadas pelo sevoflurano não promove alterações cardiorespiratórias e hemogasométricas importantes, apesar de haver diferenças significativas em alguns parâmetros entre os grupos, todos os resultados permaneceram dentro do fisiológico para a espécie felina.

PALAVRAS-CHAVE: Felus catus. Opióides. Anestesia.

\section{REFERENCES}

BERNARD, J. M.; WOUNTERS, P. F.; DOURSOUT, M. F.; FLORENCE, B.; CHELLY, J. E.; MERIN, R. G. Effects of sevoflurane and isoflurane on cardiac and coronary dynamics in chronically instrumented dogs. Anesthesiology, Philadelphia, v. 72, n. 4, p. 659-662, 1990. http://dx.doi.org/10.1097/00000542-19900400000014

BERNARD, J. M.; DOURSOUT, M. F.; WOUTERS, P.; HARTLEY, C. J.; MERIN, R. G.; CHELLY, J. E. Effects of sevoflurane and isoflurane on hepatic circulation in the chronically instrumented dog. Anesthesiology, Philadelphia, v. 77, n. 3, p. 541-545, 1992. http://dx.doi.org/10.1097/00000542-19920900000021

BOVILL, J. G.; SEBEL, P. S.; STANLEY, T. H. Opioid analgesics in anesthesia: with special reference to their use in cardiovascular anesthesia. Anesthesiology, Philadelphia, v. 61, n. 3, p. 731-55, 1984.

BOZKURT, P. Use of tramadol in children. Pediatric Anesthesia, Malden, v. 15, p. 1041-47, 2002. http://dx.doi.org/10.1111/j.1460-9592.2005.01738.x 
CLARKE, K. W.; ALIBHAI, H. I. K.; LEE, Y. H.; HAMMOND, R. A. Cardiopulmonary effects of desflurane in the dog during spontaneous and artificial ventilation. Research in Veterinary Science, London, v. 61, p. 82-6, 1996. http://dx.doi.org/10.1016/S0034-5288(96)90116-2

CHELLY, J. E. Effects of sevoflurane and isoflurane on hepatic circulation in the chronically instrumented dog. Anesthesiology, Philadelphia, v. 77, n. 3, p. 541-45, 1992. http://dx.doi.org/10.1097/00000542199209000-00021

DOBROGOWSKI, J. Influence of pre- or intraoperational use of tramadol (preemptive or preventive analgesia) on tramadol requirement in the early postoperative period. Polish Journal of Pharmacology, Cracóvia, 2002; v. 54, p. 693-97.

EBERT, T. J.; HARKIN, C. P.; MUZI, M. Cardiovascular responses to sevoflurane a review. Anesthesia Analgesia, Palo Alto, v. 81, n. 6 (Suppl), p. 11-22, 1995. http://dx.doi.org/10.1097/00000539-19951200100003

ÉVORA, P. R. B.; REIS, C. L.; FEREZ, M. A.; CONTE, D. A.; GARCIA, L. V. Distúrbios do equilíbrio hidroeletrolítico e do equilíbrio acidobásico - uma revisão prática. Medicina, Lisboa, v. 32, p. 451-69, 1999. FANTONI, D.T. Anestesia no cardiopata. In: Fantoni, D. T.; Cortopassi, S.R.G. Anestesia em Cães e Gatos. 2th ed. São Paulo: Roca; 2010. p. 464-494.

GUEDES, G. P.; NATALINI, C. C.; ROBINSON, E. P.; ALVES, S. D. L.; OLIVEIRA, S. T. Epidural administration of tramadol as an analgesic technique in dogs submitted to stifle surgery. International Journal of Applied Research in Veterinary Medicine, Apopka, v. 3, p. 352-59, 2005.

HIKASA, Y.; KAWANABE, H.; TAKASE, K.; OGASAWARA, S. Comparisons of sevoflurane, isoflurane, and halothane anesthesia in spontaneously breathing cats. Veterinary Surgery, Malden, v. 25, n. 3, p. 234-243, 1996. http://dx.doi.org/10.1111/j.1532-950X.1996.tb01407.x

HIKASA, Y.; OHE, N.; TAKASE, K.; OGASAWARA. S. Cardiopulmonary effects of sevoflurane in cats: comparison with isoflurane, halothane, and enflurane. Research in Veterinary Science, London, v. 63, p. 20510, 1997. http://dx.doi.org/10.1016/S0034-5288(97)90021-7

KAWANA, S.; WACHI, J.; NAKAYAMA, M.; NAMIKI, A. Comparison of haemodynamic changes induced by sevoflurane and halothane in paediatric patients. Canadian Journal Anaesthesia, Toronto, v. 42, n. 7, p. 603-07, 1995. http://dx.doi.org/10.1007/BF03011877

KHARASCH, E. D. Metabolism and toxicity of new anesthetic agent. Acta Anaesthesiologica Scandinavica, Copenhagen, v. 47, n. 1, p. 118-24, 1992.

KUBOTA, R.; KOMIYAMA, T.; MIWA, Y.; TAKAYUKI, I.; HAJIME, T.; FUMIKI, A.; KUKANICH, B.; PAPICH, M. G. Pharmacokinetics of tramadol and the metabolite O-desmethyltramadol in dogs. Journal of Veterinary Pharmacology and Therapeutics, Manhattan, v. 27, n. 4, p. 239-46, 2004.

http://dx.doi.org/10.1111/j.1365-2885.2004.00578.x

MASSONE, F. Anestesia inalatória. In: . Anestesiologia Veterinária: Farmacologia e Técnicas. 5. Ed. Rio de Janeiro: Guanabara Koogan, 2008. p. 80-98.

MCMILLAN, C. J.; LIVINGSTON, A.; CLARK, C. R.; DOWLING, P. M.; SUSAN, M. T.; TANYA, D.; ROLF, T. Pharmacokinetics of intravenous tramadol in dogs. Canadian Journal of Veterinary Research, Toronto, v. 72, n. 4, p. 325-31, 2008.

MILDH, L. Effects of opioids on ventilation and hemodynamics. Academic Dissertation. Department of Anesthesiology and Intensive Care Medicine University of Helsinki, Helsinki, Finland; 2007. 
MONTEIRO, E. R.; JUNIOR, A. R.; ASSIS, H. M. Q.; CAMPAGNOL, D.; QUITZAN, J. G. Comparative study on the sedative effects of morphine, methadone, butorphanol or tramadol, in combination with acepromazine in dogs. Veterinay Anaesthesia Analgesia, London, v. 36, p. 25-33, 2009.

http://dx.doi.org/10.1111/j.1467-2995.2008.00424.x

MOUTINHO, I. I. M. Estudo comparativo dos anestésicos sevoflurano vs isoflurano em coelhos (Oryctolagus cuniculus). Academic Dissertation, Universidade Técnica de Lisboa, PT, 2010.

NAVARRO, R.; WEISKOPF, R. B.; MOORE, M. A.; LOCKHART, S.; EGER, E. I.; KOBLIN, D.; LU, G.; WILSON, C. Humans anesthetized with sevoflurane or isoflurane have similar arrhythmic response to epinephrine. Anesthesiology. Philadelphia, v. 80, n. 3, p. 545-49, 1994. http://dx.doi.org/10.1097/00000542199403000-00010

NUNES, N.; POMPERMAYER, L. G.; PIROLO, J.; RAHAL, S. C. Emprego do metaraminol no bloqueio da hipotensão induzida pela levomepromazina em cães. Brazilian Journal Veterinay Research Animal Science, São Paulo, v. 32, p. 32, 120-24, 1995.

PYPENDOP, B. H.; ILKIW, J. E. Hemodinamic effects of sevoflurane in cats. American Journal Veterinay Research, Schaumburg, v. 65, n. 1, p. 20-25, 2004. http://dx.doi.org/10.2460/ajvr.2004.65.20

RADBRUCH, L.; GROND, S.; LEHMANN, K.A. A risk-benefit assessment of tramadol in the management of pain. Drug Safety, Heidelberg, v. 15, p. 8-29, 1996. http://dx.doi.org/10.2165/00002018-199615010-00002

RESENDE, M. L.; SANTOS, P. S. P.; NUNES, N.; BOLZAN, A. A. Emprego da levomepromazina no bloqueio da arritmia induzida pela adrenalina em cães anestesiados pelo sevoflurano. Ciência Rural, Santa Maria, v. 30, n. 3, p. 421-424. 2000. http://dx.doi.org/10.1590/S0103-84782000000300008

SANTOS, P. S. P.; ANDRADE, J. N. B. M.; SELMI, A. L.; COSTA, J. L. O., FALEIROS, R. R.; NUNES, N. Cardiovascular effects of desflurane following acute hemorrhage in dogs. Journal of Veterinary Emergency and Critical Care, Malden, v. 13, n. 1, p. 7-12, 2013. http://dx.doi.org/10.1046/j.1435-6935.2003.00058.x

SEDDIGHI, M. R.; EGGER, C. M.; ROHRBACH, B. W; COX, S. K.; DOHERTY, T. J. Effects of tramadol on the minimum alveolar concentration of sevoflurane in dogs. Veterinary Anaesthesia Analgesia, London, v. 36, n. 4, p. 334-40, 2009. http://dx.doi.org/10.1111/j.1467-2995.2009.00468.x

SOUZA, A. P. S.; GUERRERO, P. N. H.; NISHIMORI, C. T.; PAULA, D. P. Cardiopulmonary and acid-base effects of desflurane and sevoflurane in spontaneosly breathing cats. Journal Feline Medicine Surgery, Vancouver, v. 7, n. 2, p. 95-100, 2005. http://dx.doi.org/10.1016/j.jfms.2004.06.003

TEPPEMA, L. J.; NIEUWENHUIJS, D.; OLIEVIER, C. N.; DAHAN, A. Respiratory depression by tramadol in the cat. Anesthesiology, Philadelphia, v. 98, n. 2, p. 420-27, 2003. http://dx.doi.org/10.1097/00000542200302000-00023

WHITE, P. F. Propofol. In: Tratado de anestesia venosa. Artmed: Porto Alegre, 2001. p. 121-175.

WORDLICZEK, J.; BANACH, M.; GARLICKI. J.; JAKOWICKA-WORDLICZEK, J.; YOSHINORI, Y. Pharmacokinetics and postoperative analgesia of epidural tramadol: a prospective, pilot study. Current Therapeutic Research Clinical and Experimental, New York, v. 69, n. 1, p. 49-55, 2008. 2008. 